\title{
Plutonium measurements at NEA's North East Atlantic dumpsites
}

\author{
K. Smith ${ }^{1}$, L. León Vintró ${ }^{2}$, P.I. Mitchell ${ }^{2}$ and D. Boust ${ }^{3}$ \\ ${ }^{1}$ Radiological Protection Institute of Ireland, 3 Clonskeagh Square, Dublin 14, Ireland \\ e-mail: ksmith@rpii.ie \\ 2 UCD School of Physics, University College Dublin, Belfield, Dublin 4, Ireland \\ 3 IRSN, Laboratoire de Radioécologie, BP 10, 50130 Cherbourg-Octeville, France
}

\begin{abstract}
Surface, intermediate and near-bottom water samples were collected at two of the North East Atlantic radioactive waste dumping sites $\left(47^{\circ} 14^{\prime} \mathrm{N}, 05^{\circ} 33^{\prime} \mathrm{W}\right.$ and $\left.45^{\circ} 27^{\prime} \mathrm{N}, 06^{\circ} 16^{\prime} \mathrm{W}\right)$ in the course of a sampling campaign in June-July 1998. Analysis of ${ }^{239,240} \mathrm{Pu}$ concentrations show no significant differences with respect to measured concentrations in waters taken from control (background) stations well removed from the dumping sites.
\end{abstract}

\section{INTRODUCTION}

For almost 30 years, low-level radioactive waste resulting from research, industry, medical, military, and nuclear fuel cycle activities was dumped at various sites in the North East (NE) Atlantic [1-3]. These dumping sites were routinely monitored over the period 1977 to 1995 as part of the Co-ordinated Research and Environmental Surveillance Programme Related to Sea Disposal of Radioactive Waste (CRESP) by the Nuclear Energy Agency but, to our knowledge, few measurements have been reported in the open literature since the final report by CRESP was issued in 1996 [4].

In this paper, we present the results of ${ }^{239,240} \mathrm{Pu}$ analyses carried out on water samples taken at two of the NE Atlantic dumpsites in 1998. The measured concentrations are compared with those at three, far removed, control sites and with ${ }^{239,240} \mathrm{Pu}$ sea water profiles measured previously in the NE Atlantic dumping sites.

\section{RADIOACTIVE WASTE DUMPING IN THE WORLD'S OCEANS}

For almost 50 years, starting in 1946, a number of countries used sea disposal as a radioactive waste management option. It has been estimated that, over this period, approximately $85 \mathrm{PBq}$ of radioactive waste was dumped at more than 80 locations in the Kara Sea, Atlantic, Pacific, and Arctic Oceans by 14 countries $[3,5]$.

Just over half of the total activity in the disposed radioactive waste was low level packaged solid waste. The majority of this packaged waste was disposed in the NE Atlantic. The Kara Sea was used by the former Soviet Union as a dumping site for reactors with spent nuclear fuel. This represented almost $44 \%$ of the activity in the disposed radioactive waste. The remainder of total activity dumped was $1.6 \%$ in the Arctic Ocean, as low level liquid and solid waste, and $1.7 \%$ in the Pacific Ocean [5].

\subsection{North East Atlantic Dumpsites}

The IAEA [5] has reported that more than $93 \%$ of packaged low-level radioactive material disposed of in the oceans was dumped in the NE Atlantic Ocean dumpsites. These dumpsites were sited below $50^{\circ} \mathrm{N}$ and at depths greater than 4000 meters. From 1954 until 1982, $666 \mathrm{TBq}$ of alpha emitters, 


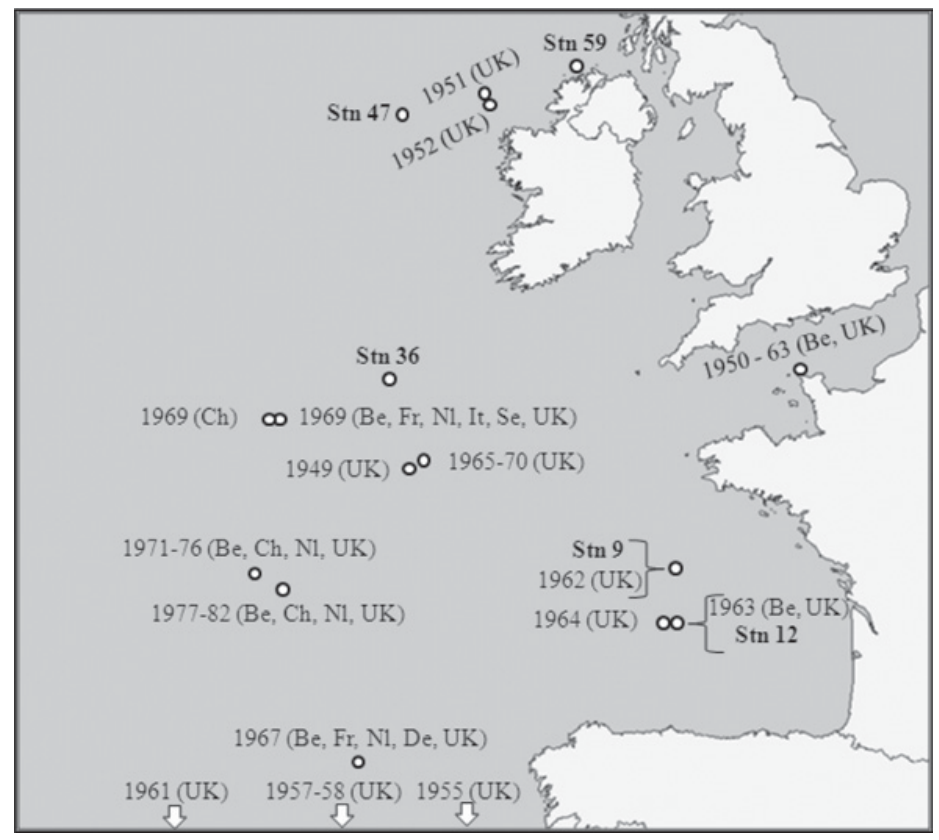

Figure 1. The location of low level radioactive waste dumping sites in the NE Atlantic. Also shown (bolded text) are the UCD seawater sampling sites.

26,146 TBq of $\beta / \gamma$ emitters, and 15,474 TBq of tritium were disposed in various NE Atlantic Ocean dumpsites $[2,3,5]$.

Typically $98 \%$ of the total radioactivity disposed in these dumping sites consisted of tritium and other $\beta / \gamma$ emitters such as ${ }^{90} \mathrm{Sr},{ }^{134} \mathrm{Cs},{ }^{137} \mathrm{Cs},{ }^{55} \mathrm{Fe},{ }^{58} \mathrm{Co},{ }^{60} \mathrm{Co},{ }^{125} \mathrm{I}$ and ${ }^{14} \mathrm{C}$. The remainder of the radioactivity in these waste resulted from alpha-emitting radionuclides. Plutonium and americium isotopes represent $96 \%$ of the alpha-radioactivity. The low level waste included paper and textiles from decontamination processes, resins and filters, etc. The waste was solidified with cement or bitumen and packaged in metal containers $[3,5,6]$.

The NE Atlantic dumping sites were routinely subject to radiological survey over the period 1977 to 1995. In 1992, the IAEA Marine Environment Laboratory (MEL), the Bundesforschungsanstalt fur Fischerei (BFA), Germany, and the Fisheries Laboratory of the Ministry of Agriculture, Fisheries and Food (MAFF), United Kingdom participated in site specific measurements at the largest dumpsites in the NE Atlantic. In this campaign samples collected above the sea-bed of the main dumpsites were analysed for ${ }^{14} \mathrm{C},{ }^{137} \mathrm{Cs},{ }^{238} \mathrm{Pu},{ }^{239,240} \mathrm{Pu}$ and ${ }^{241} \mathrm{Am}$. The analysis showed local enhancements of activities at the dumping sites, suggesting measurable leakages, although of negligible radiological impact [5].

\section{EXPERIMENTAL AREA}

Samples of surface, intermediate and near-bottom seawater were collected at two low level radioactive waste dumping sites $\left(47^{\circ} 14^{\prime} \mathrm{N}, 05^{\circ} 33^{\prime} \mathrm{W}\right.$ and $\left.45^{\circ} 27^{\prime} \mathrm{N}, 06^{\circ} 16^{\prime} \mathrm{W}\right)$ from aboard the R.V. Suroît in June-July 1998. In addition, sea water samples were retrieved at three control sites (Stn36, Stn47, Stn 59) well removed from the dumping sites. The five sampling locations are shown in Figure 1.

Sampling station 9 ( $\operatorname{Stn} 9$ ) corresponds with a 1962 UK dumping site, while sampling station 12 (Stn12) was located at a 1963 UK - Belgium dumping site. Table 1 reports the locations of the two dumpsites and the quantities of low level radioactive waste disposed off. 
Table 1. The locations and quantities of low level radioactive waste dumped at two of NE Atlantic dumpsites [5].

\begin{tabular}{|c|c|c|c|c|c|c|c|c|}
\hline \multirow[t]{2}{*}{ Year } & \multirow[t]{2}{*}{ Lat (N) } & \multirow[t]{2}{*}{ Lon (W) } & \multirow{2}{*}{$\begin{array}{c}\text { UCD } \\
\text { Station }\end{array}$} & \multirow[t]{2}{*}{ Country } & \multirow{2}{*}{$\begin{array}{l}\text { Weight } \\
\text { (t) }\end{array}$} & \multicolumn{3}{|c|}{ Activity (GBq) } \\
\hline & & & & & & $\beta-\gamma$ & $\alpha$ & Total \\
\hline 1962 & $46^{\circ} 27^{\prime}$ & $6^{\circ} 10^{\prime}$ & Stn 9 & UK & 253 & 6031 & 629 & 6660 \\
\hline 1963 & $45^{\circ} 27^{\prime}$ & $6^{\circ} 16^{\prime}$ & Stn 12 & UK & 5809 & 261627 & 13616 & 275243 \\
\hline 1963 & $45^{\circ} 27^{\prime}$ & $6^{\circ} 16^{\prime}$ & Stn 12 & Belgium & 789 & 2220 & 40 & 2260 \\
\hline
\end{tabular}

Table 2. ${ }^{239,240} \mathrm{Pu}\left(\mathrm{mBq} \cdot \mathrm{m}^{-3}\right)$ measured in the NE Atlantic seawater samples in June-July 1998.

\begin{tabular}{|c|c|c|c|c|c|c|}
\hline \multirow{2}{*}{$\begin{array}{l}\text { Station } \\
\text { Code }\end{array}$} & \multirow{2}{*}{$\begin{array}{l}\text { Sampling } \\
\text { Depth (m) }\end{array}$} & \multirow[t]{2}{*}{ Lat $(\mathbf{N})$} & \multirow[t]{2}{*}{ Lon $(\mathbf{W})$} & \multicolumn{3}{|c|}{${ }^{239,240} \mathrm{Pu}\left(\mathrm{mBq} \mathrm{m}^{-3}\right)$} \\
\hline & & & & Filtrate & Particulate & Total \\
\hline \multirow[t]{3}{*}{ Stn. 9} & 10 & $46^{\circ} 27^{\prime}$ & ${ }^{\circ} 10^{\prime}$ & $4.5 \pm 0.4$ & $1.5 \pm 0.2$ & $6.0 \pm 0.4$ \\
\hline & م & $46^{\circ}$ & & $9.3 \pm 0.6$ & & $15.2 \pm 0.8$ \\
\hline & & & & 2.5 & & $3.2 \pm$ \\
\hline \multirow[t]{2}{*}{ Stn. 12} & 1( & & & 3.8 & & $5.3 \pm$ \\
\hline & & & & 4.6 & & $5.1 \pm$ \\
\hline \multirow[t]{2}{*}{$\operatorname{Stn} .36^{\dagger}$} & 10 & & & $1.0 \pm 0.4$ & 1.4 & $2.4 \pm 0.6$ \\
\hline & 900 & $50^{\circ}$ & $14^{\circ}$ & $14.4 \pm 1.5$ & $<0$ & $14.4 \pm 1.5$ \\
\hline \multirow[t]{3}{*}{ Stn. 47} & 10 & $55^{\circ} 00^{\prime}$ & $14^{\circ} 00^{\prime}$ & $2.6 \pm 0.6$ & $0.52 \pm 0.13$ & $3.1 \pm 0.6$ \\
\hline & 15 & & & $11.3 \pm 1.8$ & & $12.7 \pm 1.9$ \\
\hline & 270 & & & & & $6.2 \pm 1.2$ \\
\hline Stn. 59 & 10 & $55^{\circ} 19^{\prime}$ & $08^{\circ} 18^{\prime}$ & $4.9 \pm 1.0$ & $1.2 \pm 0.3$ & $6.1 \pm 1.0$ \\
\hline
\end{tabular}

${ }^{\dagger}$ Near-bottom waters were not recovered at this control station.

\subsection{Materials and Methods}

At the sampling locations, near-surface sea water samples were taken at depths of $\sim 10 \mathrm{~m}$ below the surface using a ship deck pump, while deeper samples were taken with large volume rosette samplers. Following retrieval, samples (25-75 litres) were promptly filtered through large area membrane filters $(<0.45 \mu \mathrm{m})$ and ${ }^{239,240} \mathrm{Pu}$ in the filtered fraction was pre-concentrated in situ by coprecipitation with ferric hydroxide. To effect the pre-concentration, samples were acidified with $12 \mathrm{M} \mathrm{HCl}$ to a pH of 1.5. Following the addition of a certified ${ }^{236} \mathrm{Pu}$ yield monitor and $\mathrm{Fe}^{3+}$ carrier, samples were vigorously stirred to ensure complete equilibration of yield monitor and determinant. The coprecipitation of plutonium with ferric hydroxide was then achieved by adjusting the $\mathrm{pH}$ of each sample to between 7.5 and 8 using ammonia. The precipitate, containing the plutonium, was collected by filtration through $0.45 \mu \mathrm{m}$ membranes and stored for subsequent analysis.

Plutonium in the filters containing the $\mathrm{Fe}(\mathrm{OH})_{3}$ precipitate or suspended particulate was purified using standard radiochemical techniques [7]. Each purified sample was then electroplated onto a polished stainless-steel disc from a mixed ammonium oxalate/ammonium chloride medium. The activity of ${ }^{239,240} \mathrm{Pu}$ was determined by low-background, high-resolution alpha spectrometry. In most cases, ${ }^{238} \mathrm{Pu}$ activity concentrations were too low to allow accurate quantification.

\section{RESULTS}

The results of the plutonium analyses on seawater samples taken from the NE Atlantic dumpsites and at control sites are given in Table 2. The data show no evidence of significant differences between the measured ${ }^{239,240} \mathrm{Pu}$ concentrations at the two dumpsites and those at the control stations. Our measured total ${ }^{239,240} \mathrm{Pu}$ concentrations in surface waters (mean $=4.6 \pm 1.7 \mathrm{mBq} \mathrm{m}^{-3}$; range $=2.4-6.2 \mathrm{mBq} \mathrm{m}^{-3}$ ) are similar to those reported in the early 1990s by Holm et al. [8], but a factor of 13 lower than those measured in NE Atlantic waters during 1972 (GEOSECS programme) [9]. As seen in other oceans and 


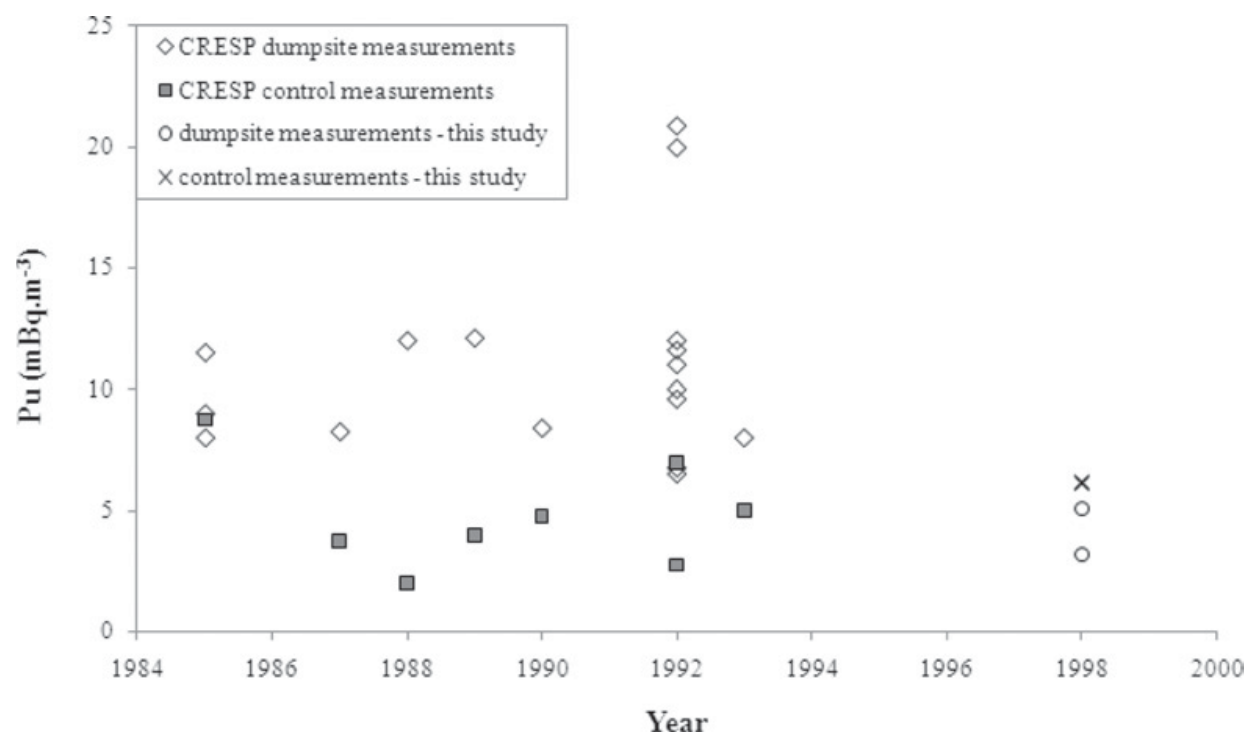

Figure 2. Plutonium concentrations in seawater samples taken above the sea bed at NE Atlantic dumpsites and control sites (Data from CRESP final report [4] and present study).

previously reported for the NE Atlantic [8, 10], the rapid decline in surface plutonium concentrations is a consequence of its removal in association with sinking particles, as well as physical mixing. The association of plutonium with suspended particulate material is evident from our data, which show that a significant proportion of the plutonium in surface waters (mean $=30 \pm 16 \%$; range $=17-58 \%$ ) is bound to particulate material.

Much of the removed plutonium is subsequently released to intermediate waters, giving rise to a subsurface maximum in the 200-1000 $\mathrm{m}$ depth range [11]. The presence of such a subsurface maximum is evident at Stations 9, 36 and 47, where intermediate depth water samples were collected. Here, ${ }^{239,240} \mathrm{Pu}$ concentrations at mid-depths were found to be 3-6 times higher than those in the surface. The distribution of plutonium below depths ventilated physically from the surface results from the transport of plutonium in association with sinking particles which, on descent, may be subject to oxidation, bacterial degradation, and demineralisation, with the consequent release of plutonium back into solution $[10,12]$.

Concentrations in near-bottom waters at the two dumpsites (Stations 9 and 12) are indistinguishable from the (near-bottom water) concentration measured at our Station 47 control site, and also to those reported for control sites in the CRESP final report (Figure 2) [4]. Elevated ${ }^{238} \mathrm{Pu} /{ }^{239,240} \mathrm{Pu}$ activity ratios with respect to fallout have been reported for sediments and bottom waters close to dumped waste at some locations within the dumping sites [6], which can be taken as evidence of limited leakage. As of 1998, the influence of this possible leakage on water concentrations throughout the dumping sites and the general area surrounding the sites appears to be negligible.

\section{CONCLUSION}

Analyses of ${ }^{239,240} \mathrm{Pu}$ concentrations in waters collected from two NE Atlantic radioactive waste dumping sites in June-July 1998 show no evidence of leakage from the dumped waste, with measured concentrations compatible with those expected from global weapons fallout alone. No differences were observed in the measured concentrations between the waters collected at the dumpsites and those collected at control sites, well removed from these sites. 


\section{Acknowledgements}

The authors wish to acknowledge the support received from the captain and crew of the R.V. Suroit during the ATMARA research expedition in 1998. In addition, the authors wish to thank C. Organo and S. Long (RPII) for reviewing this article.

\section{References}

[1] Calmet D.P. and Bewers J.M., Marine Policy, 15 (1991) 413-430.

[2] Templeton W.L., Mar. Pollut. Bull. 35 (1997) 374-380.

[3] Thiel, H. "Anthropogenic Impacts on the Deep Sea", Ecosystems of the Deep Oceans, P.A. Tyler Ed. (Elsevier Science, London, 2003).

[4] NEA, Co-ordinated Research and Environmental Surveillance Programme Related to Sea Disposal of Radioactive Waste - CRESP Final Report, (OECD Publications, Paris, 1996).

[5] IAEA, "Inventory of radioactive waste disposals at sea: IAEA-TECDOC-1105", (International Atomic Energy Agency, Waste Safety Section, Vienna, 1999).

[6] Baxter M.S., Fowler S.W. and Povinec P.P., Appl. Radiat. Isot., 46 (1995) 1213-1223.

[7] León Vintró L. and Mitchell P.I., "Determination of actinides and other alpha emitters in environmental samples", Encyclopedia of Analytical Chemistry: Instrumentation and Application, R.A. Meyers Ed. (John Wiley \& Sons, London, 2000) pp. 12848-12884.

[8] Holm E., Roos P., Persson R.B., Bojanowsky R., et al., "Radiocaesium and plutonium in Atlantic surface waters from $73^{\circ} \mathrm{N}$ to $72^{\circ} \mathrm{S}$ ", Radionuclides in the Study of Marine Processes, (Springer, Norwich, 1991) pp. 3-11.

[9] Livingston H.D., Bowen V.T., Casso S.A., Volchock H.L., et al., Fallout Nuclides in Atlantic and Pacific Water Columns: GEOSECS Data, (Woods Hole Oceanographic Institution, Massachusetts USA, 1985).

[10] Nyffeler F., Cigna A.A., Dahlgaard H., and Livingston H.D, "Radionuclides in the Atlantic Ocean: A Survey", Radionuclides in the Ocean: Inputs and Inventories, P. Guegueniat, P. Germain, and H. Metivier Eds. (Les Editions de Physique, Paris, 1996) pp. 1-28.

[11] León Vintró L., Mitchell P.I., Smith K.J., Kershaw P.J. and Livingston H.D., "Transuranium Nuclides in the world's Oceans", Marine Radioactivity, Radioactivity in the Environment Series, H. D. Livingston Ed. (Elsevier Science Ltd, London, 2004) pp. 79-108.

[12] Sholkovitz E.R., Earth Sci. Rev. 19 (1983) 95-161. 